
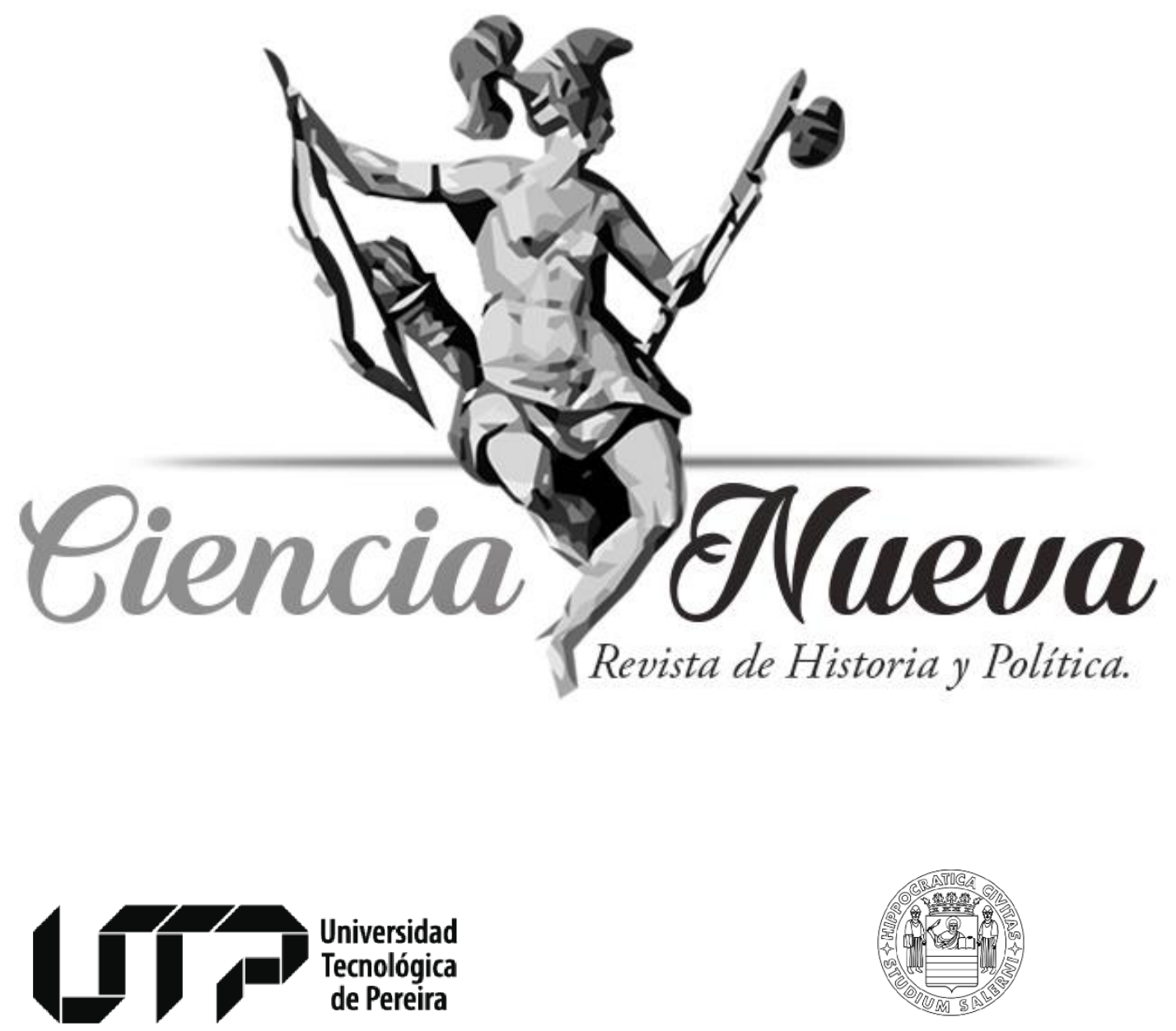

UNIVERSITÀ DEGLI STUDI DI SALERNO

Maestría en Historia

Maestría en Ciencia Política

DOSSIER: HISTORIA SOCIAL DEL SIGLO XVIII

EL CONCEPTO DE LIBERTAD EN ALGUNAS DECLARATORIAS DE INDEPENDENCIA DEL RÉGIMEN PROVINCIAL ESPAÑOL

(1780-1821)

THE NOTION OF FREEDOM IN SOME INDEPENDENCE'S DECLARATIONS OF THE SPANISH

PROVINCIAL REGIME (1780-1821)

Sonia Milena Jaimes Peñaloza

pp. $115-142$

Vol. $1 N^{o}$ 2, Julio-Diciembre de 2017

Pereira, Colombia 


\title{
EL CONCEPTO DE LIBERTAD EN ALGUNAS DECLARATORIAS DE INDEPENDENCIA DEL RÉGIMEN PROVINCIAL ESPAÑOL $(1780-1821)^{*}$ \\ THE NOTION OF FREEDOM IN SOME INDEPENDENCE'S DECLARATIONS OF THE SPANISH PROVINCIAL REGIME (1780-1821)
}

\author{
Sonia Milena Jaimes Peñaloza** \\ sonmil@gmail.com \\ ORCID: https://orcid.org/0000-0003-2293-7702
}

\author{
Recibido: 08 de abril de 2017 \\ Revisado: 14 de mayo de 2017 \\ Aceptado: 22 de junio de 2017 \\ Publicado: 22 de agosto de 2017
}

\begin{abstract}
Resumen:
El objetivo de este artículo es analizar comparativamente, desde la lógica de la historia conceptual, la idea de libertad plasmada en unas pocas declaratorias de independencia escritas en el periodo 1811-1821. Estos documentos fueron la evidencia del clima de opinión con el que se articuló la ilusión de una época. En estas declaratorias se plasmó la utopía de un futuro político que se imaginaba distinto al régimen monárquico español, y que para los territorios ultramarinos de esta monarquía significaron la transformación de la idea de Estado hasta entonces conocida. Las declaratorias se convirtieron en los ordenadores sociales y políticos que modelaron los horizontes de expectativa, dándole sentido a los nuevos regímenes de verdad del periodo en referencia. Ellas fueron las semillas de una nueva conciencia histórica que enlazó varios eventos históricos con la formación de una nueva semántica política, donde el lenguaje se configuró como una nueva experiencia de tiempo, en cuyo seno emergieron las tensiones de la nueva realidad política y social que vivía el régimen español continental y ultramarino occidental.
\end{abstract}

Palabras clave:

Libertad, clima de opinión, horizontes de expectativa, regímenes de verdad, semántica política, cultura política, cultura jurídica, Estado.

\begin{abstract}
:
The aim of this paper is analyzing comparatively, based on the conceptual history's logic, the notion of freedom written down in a few independence's declarations written between 1811 and 1821. These documents were the evidence of the climate of opinion that articulated the illusion of an age. On these declarations was written down the utopia of a political future idealized different regarding the Spanish monarchic regime, which meant to its overseas territories the transformation of the notion of State until then known. The declarations became the political and social organizers, with which were shaped the horizons of expectation that allowed the new regimes of truth during this period to make sense. Those were the seeds of a new historical consciousness that related several historical events to the creation of a new political semantics, which the language shaped itself as a new experience of time within emerged the tensions of the new political and social reality that began to be lived in the continental and western overseas Spanish regime.
\end{abstract}

\section{Keywords:}

Freedom, climate of opinion, horizons of expectation, regimes of truth, political semantics, political culture, legal culture, State.

\footnotetext{
* El presente artículo respeta las directrices y normas dispuestas en la Declaración de Ética de Publicación de Ciencia Nueva, Revista de Historia y Política. Esta declaración puede consultarse en la página web de la revista: revistas.utp.edu.co/index.php/historia

${ }^{* *}$ Licenciada en Historia de la Universidad del Valle, magíster en Historia de la Universidad Nacional de Colombia Sede Bogotá, doctoranda en Historia Latinoamericana en la Universidad Andina Simón Bolívar (Quito), profesora del Departamento de Economía de la Facultad de Ciencias Administrativas y Económicas de la Universidad ICESI.
} 
Modern professional historical studies were born in the nineteenth century - of a desire for knowledge of the past free of all theological, metaphysical, and ideological preconception and productive of detailed information about the natures of those peoples aspiring to nationhood in the wake of the French Revolution. History was to be studied in an objective and disinterested manner in order to construct a picture of historical reality by which to measure the falsity of various ideological constructions thereof. But since ideology was thought to be a result of theory overriding the gathering of information about the past-as witnessed by the nefarious effects of philosophy of history on social and political thought-historical studies remained caught on the horns of a dilemma: in order to become a science, they had to have a theory; but an interest in theory appeared to foreclose that interest in particular facts about the past in which historical studies was focused. The resolution of this dilemma was, however, implicitly contained within what came to be called the historist (or historicist) vision of historical reality, which posited historicity as not only a specifically social mode of being in the world but also a social mode of being in the world marked by a particular experience of temporality.

Hayden White ${ }^{1}$.

$\mathrm{E}_{\mathrm{d} t}^{1}$ 114 de julio de 1789 una turba enardecida se dirigió a La Place de la Bastille -aquella edificación que bajo el mandato de Carlos V de Francia había servido para la defensa de la ciudad de París, y se transformó en cárcel estatal en los tiempos del Armand Jean du Plessis más conocido como el Duque y Cardenal de Richelieu-, el objetivo era apropiarse de la pólvora y las armas que allí se guardaban. El tumulto buscaba tomarse la justicia y enfrentar los actos despóticos de Louis XVI; el levantamiento era la costumbre moral de los campesinos, y en el siglo XVIII fue la lógica de su politicidad. Tal como se ha demostrado en la literatura especializada sobre el periodo, los reclamos, protestas y las representaciones del pueblo llano eran su manera de vincularse con las políticas reformistas imperantes en los reinos de Francia, Inglaterra y España a finales del siglo XVIII ${ }^{2}$.

Los hechos del 14 de julio de 1789 desencadenaron la destitución de Jacques Necker, el ministro de finanzas del reino, quien puso en evidencia los despilfarros de la monarquía y su corte, y quien había sugerido transformaciones económicas en pro del bien común. Las sugerencias de J. Necker habían sido bien recibidas por la opinión pública de entonces ${ }^{3}$, pues

\footnotetext{
${ }^{1}$ Prólogo de Reinharts Koselleck, The practice of conceptual history: Timing history, spacing concepts (Estados Unidos de América: Stanford University Press, 2002).

${ }^{2}$ Para detalles sobre los sentidos y significados de las protestas campesinas a finales del siglo XVIII en los reinos mencionados ver, entre otros: E.P. Thompson, Costumbres en común (Barcelona: Crítica, 1995). Margarita Garrido, Reclamos y representaciones-variaciones sobre la política en el Nuevo Reino de Granada, 1770 - 1815 (Bogotá: Banco de la República, 1993). Germán Feijoo y Zoila Ubillus, "Levantamientos populares coloniales: Hato de Lemos 1781", Revista Región, No 5 (1996): 35-59. Steve Stern, comp., Resistencia, rebelión y conciencia campesina en los Andes. Siglos XVIII-XX (Lima: Instituto de Estudios Peruanos-IEP, 1990), 13-41. Peter Guardino, El tiempo de la libertad. La cultura política popular en Oaxaca, 1750-1850 (Universidad Autónoma Metropolitana-Unidad Iztapala/Universidad Autónoma Benito Juárez de Oaxaca/Colegio de Michoacán/Colegio de San Luis/Congreso del Estado de Oaxaca/Durham and London, Duke University Press, 2005).

${ }^{3}$ Sobre la opinión pública del siglo XVI al XVIII, hay debates que plantean que esta sí existió y que no es propia o exclusiva del siglo XX, postura que comparto. Para conocer más sobre cómo se formó la opinión pública del periodo en referencia ver: Natalia Silva Prada, "Pasquines contra visitadores reales: opinión pública en las ciudades hispanoamericanas de los siglos XVI, XVII y XVIII”, en Opinión pública y espacio urbano en la Edad Moderna, dir. por James S. Amelang y Antonio Castillo Gómez, ed. por Carmen Serrano (Gijón: Ediciones Trea S.L., 2010), 373-398. Natalia Silva Prada, “Cultura política tradicional y opinión crítica: los rumores y pasquines iberoamericanos de los siglos XVI al XVIII”, en Tradición y modernidad en la historia de la cultura política (siglos XVI-XX), coord. Por Riccardo Forte y Natalia Silva Prada (México D.F.: Universidad
} 
la crisis económica del reino se expresaba en hambrunas y escasez diferenciada por todo el territorio francés.

La toma de la Bastille evidenciaba las tensiones políticas que se vivían en el reino de Francia, muchas vinculadas con las reformas fiscales que desde 1788 se habían tratado de implementar. Dichas reformas eran por principio desiguales, pues los nobles guardaron sus privilegios mientras que el resto del pueblo debió asumir nuevas cargas. Un proceso similar se trató de realizar en el reino de España -eso sí, las circunstancias internas de este último eran bastante disímiles comparadas con las de los galos-, lo que había ocasionado inconformidades $\mathrm{y}$ tensiones de distinto alcance en ambos reinos, por supuesto con profundidades diferentes en cada caso.

Este reformismo expresaba el ambiente modernista ${ }^{4}$ que se estaba empezando a tejer en la Europa continental occidental, y se anclaba en la formación del pensamiento ilustrado, cuyos sentidos eran no solo tecnificar la agencia gubernamental, sino -en el caso de Franciasalirle al paso a la crisis económica que la guerra con Inglaterra estaba causando. Simultáneamente se buscaba solucionar la crisis alimentaria que el crecimiento demográfico y el aumento de la peste habían causado en el periodo $1760-1770^{5}$, circunstancias de las que aquel reino no había logrado recuperarse totalmente.

Para entonces, las ideas de libertad e igualdad difundidas en las obras de FrançoisMarie Arouet Voltaire, Jean Jacques Rousseau y Charles-Louis de Secondat -mejor conocido como el barón de Montesquieu-, empezaban a ser hegemónicas en el discurso político ilustrado francés -que incluso alcanzó a las mentes más progresistas del reino español como lo fue la del Conde de Aranda -, o si se quiere, de lo que para entonces se puede denominar la politicidad de la nueva cultura política ${ }^{6}$ moderna. Se trataba de una cultura política con tendencias jacobinas que valoraba lo meritocrático, desplazando, tangencialmente, la sociedad de los valores estamentales asociada con los privilegios. Esta transformación, tanto del pensamiento como de las prácticas políticas, le dio un nuevo lugar en la arena pública francesa a hombres como Maximilien Robespierre, un abogado sin abolengos, pero con grandes capacidades para pensar la estructura de un nuevo régimen estatal. Así se empezaban a tejer lo que en la historiografía política occidental se conoce como las "consecuencias culturales [y políticas] de la Revolución francesa para el moderno sistema-mundo como un todo" $"$.

En medio de la algarabía del 14 de julio de 1789, mujeres del pueblo llano francés se dirigieron a Versalles, su meta era encontrar a la reina: María Antonieta y ajusticiarla. Se

Autónoma Metropolitana-Unidad Iztapalapa, 2009), 89-143. Natalia Silva Prada, "Los reinos de las indias" y el lenguaje de denuncia política en el mundo Atlántico (s. XVIXVII). Charleston: Create Space, 2014.

${ }^{4}$ Sobre el problema de la modernidad, la literatura especializada es amplia, entre otros ver: Lynn Hunt, “Modernity: Modern Times Different?", Historia Crítica, No 54 (2014): 107-124. Jorge Orlando Melo, "Algunas consideraciones globales sobre 'modernidad' y 'modernización", en Colombia. El despertar de la modernidad, comp. por Fernando Viviescas y Fabio Giraldo (Bogotá: Ediciones Foro Nacional por Colombia, 1991). Luis Javier Orjuela, "La tensión entre tradición y modernidad (1904-1995)", en Historia de las ideas políticas en Colombia. De la independencia hasta nuestros días, Javier Ocampo López (Bogotá: Taurus, 2008). ${ }^{5}$ Gregory Clark, Adiós a la sopa de pan, hola al sushi. Breve historia económica mundial (Valencia: Universitat de Valencia, 2014), 39-218.

${ }^{6}$ Para detalles sobre lo que es cultura política ver: Sonia Milena Jaimes Peñaloza, Teatrocracia y legislación electoral colombiana (1886-1938). Un estudio de y sobre cultura política y democracia (Bogotá: Universidad del Rosario, 2012), 15-62.

${ }^{7}$ Immanuel Wallerstein, El moderno sistema mundial. El triunfo del liberalismo centrista, 1789-1914 (México: Siglo XXI Editora Iberoamericana S.A., 2014), 17. 
consideraba que ella era en gran medida responsable de las desgracias del pueblo francés. No solo por austriaca, sino por su conducta palaciega -que se asociaba tanto con el endeudamiento que acarreó a las finanzas del Estado, como al hecho de no haber concebido un heredero hasta 1777-. La reina pudo esconderse con su familia, pero prácticamente desde entonces, la familia real, se mantuvo prisionera por los revolucionarios en el palacio de Tuileries.

Tras los actos del 14 de julio de 1789, en Francia se instauró una monarquía constitucional, liderada por M. Robespierre y anclada a los ideales de libertad, igualdad y fraternidad $^{8}$. Estos fueron los pilares de la nueva política estatal francesa, y se convirtieron con el tiempo en las utopías del futuro político de carácter republicano occidental ${ }^{9}$. Con este acto se inició una cadena de acontecimientos que marcaron el final del Ancien Régime, no solo en el reino de Francia. Así las cosas, cabe preguntarse: ¿cómo afectó esta situación al reino español de entonces?

Para acercarse a comprender dicho proceso, mi argumento principal busca demostrar que entre 1780 y 1821 el mundo occidental transformó la noción de Estado y con ella mutaron tanto las formas de hacer política como la semántica propia de la arena pública. Es por ello que vocablos como: libertad, liberal, liberación se llenaron de contenido político distinto, y se sumaron a otras palabras como jacobino, jacobinismo, república y democracia, entre otros, para tejer los rostros del Estado nuevo, la institución con la que desde entonces se ha modelado la politicidad moderna y contemporánea occidental. Es preciso tener presente que los acontecimientos parisinos de 1789 legitimaron no solo la idea liberal del mundo político de entonces, sino que transformaron la idea de soberanía, la cual dejó de vincularse exclusivamente con la lógica del derecho natural, y se empezó a vislumbrar el pacto social que los iusnaturalistas venían planteando desde sus disquisiciones filosóficas. Por ende, considero que en aquella coyuntura se produjo una nueva cultura política, en la que la soberanía dejó de reposar exclusivamente en los soberanos; la noción o idea de pueblo mutó y empezó a ser el repositorio de aquella soberanía política ${ }^{10}$. Claro está que esta transmutación no se hizo de un día para otro, el cambio exigió de un espacio temporal, así como uno político para materializarse. Por ello, el periodo que va de 1780 a 1821 fue un punto de inflexión en el que la laicidad de la arena pública posibilitó armar varios proyectos estatales en los que las ideas ilustradas cimentaron los fundamentos de la política moderna. En medio de dicha transformación las declaratorias de independencia de los territorios provinciales españoles, tanto como las de las colonias francesas y británicas, son la punta del iceberg con la que podemos comprender el lugar de la noción de libertad que se le imprimió al Estado nuevo.

Estas transformaciones políticas evidencian cómo cada sociedad construye su propia experiencia de tiempo - pasado, presente y futuro - y, en consecuencia, sus propios regímenes

\footnotetext{
${ }^{8}$ Estos principios se fundamentaron en la declaración de los derechos del hombre y el ciudadano. Para detalles ver: "Declaration des droits de l'homme et du citoyen". Acceso noviembre de 2014, http://www.legifrance.gouv.fr/Droitfrancais/Constitution/Declaration-des-Droits-de-l-Homme-et-du-Citoyen$\underline{\text { de-1789 }}$

${ }^{9}$ Sobre la idea de utopías políticas volveré más adelante.

${ }^{10}$ María Teresa Calderón y Clément Thibaud, "La construcción del orden en el paso del antiguo régimen a la república. Redes sociales e imaginario político del Nuevo Reino de Granada al espacio Grancolombiano", Anuario Colombiano de Historia Social y de la Cultura, No 29 (2002): 135-165. María Teresa Calderón y Clément Thibaud, La majestad de los pueblos en la Nueva Granada y Venezuela, 1780-1832 (Bogotá: Taurus, 2010).
} 
de verdad ${ }^{11}$. En tales experiencias, el tiempo se asume como una categoría que se ordena de acuerdo con la conciencia que cada sociedad tiene o construye de sí misma, y de aquellas que le son contemporáneas. Es justamente en esta lógica, que el reino de España -donde se deben incluir los territorios ultramarinos que en adelante se denominarán mundo provincial español occidental- construyó su régimen de historicidad ${ }^{12}$ moderno. Se trató de un régimen que buscó modificar el orden monárquico para construir un ordenamiento político distinto al monárquico, se denominó republicano y se amparó en los principios de la libertad y la igualdad.

El objetivo de estas páginas es analizar comparativamente, desde la lógica de la historia conceptual encadenada por Reinhart Koselleck, la idea de libertad plasmada en unas pocas declaratorias de independencia escritas en el periodo 1811-1821 ${ }^{13}$. Estos documentos fueron la evidencia del clima de opinión con el que se articuló la ilusión de una época ${ }^{14}$. En estas declaratorias de independencia se plasmó la utopía de un futuro político que se imaginaba distinto al régimen monárquico español, y que para los territorios ultramarinos de esta monarquía significaron la transformación de la idea de Estado hasta entonces conocida. Las declaratorias se convirtieron en los ordenadores sociales y políticos que modelaron los horizontes de expectativa, dándole sentido a los nuevos regímenes de verdad del periodo en referencia. A mi modo de ver, ellas fueron las semillas para el nacimiento de una nueva conciencia histórica que entrelazó varios eventos históricos con la formación de una nueva semántica política. De esta manera, el lenguaje se configuró como una nueva experiencia de tiempo, en cuyo seno emergieron las tensiones de la nueva realidad política y social que vivía el régimen español continental y ultramarino occidental.

Dicha semántica política sentó las bases de la transformación ideológica que le dio sentido a la política moderna. Los hombres que defendieron las nuevas ideas en pro de un Estado no necesariamente monárquico como se había conocido hasta la coyuntura de finales del siglo XVIII, forjaron una "imaginería puramente fantasiosa, colocada en el futuro"15. Se trató de una imaginería en la que la agencia individual fue la clave de su coordinación. Dado que se trataba de una fantasía pensada a futuro, se puede sostener que en la transformación política de 1780 hasta 1821 se construyeron nuevas utopías, las cuales, a modo de mundos artificiales, fundamentaron el nacimiento de lo que actualmente, y de forma naturalizada, denominamos: ideología liberal, convertida desde entonces en el sustrato de la constitución de los Estados modernos y sus herederos contemporáneos ${ }^{16}$. Aquellas declaratorias fueron el pacto de libertad para los territorios ultramarinos, tanto del régimen provincial español como para las colonias francesas y británicas, fueron el futuro-pasado ${ }^{17}$ de la política occidental.

\footnotetext{
${ }^{11}$ Reinhard Koselleck, Futuro pasado. Para una semántica de los tiempos históricos (Barcelona: Paidós, 1993), 11-17, 127-128, 141.

${ }^{12}$ François Hartog, Regímenes de historicidad (México D.F.: Universidad Iberoamericana-Departamento de Historia, 2007), 16, 20-21, 30, 130-180.

13 La autora agradece a Armando Martínez Garnica por su generosidad al cederle las declaratorias de independencia de las provincias del Virreinato de la Nueva Granada que sirvieron de insumo para la elaboración de este ensayo.

14 Joseph S Roucek y Ángela Müller Montiel. "Historia del concepto de ideología”, Revista Mexicana de Sociología 25, No 2, (1963): 667.

${ }^{15}$ Roucek y Müller, "Historia del concepto de ideología", 675.

${ }^{16}$ Wallerstein, El moderno sistema mundial..., 21-118.

${ }^{17}$ Las reflexiones que incorporo en este texto se vinculan directamente con la propuesta de Reinhart Koselleck quien nos invita a pensar en los estratos del tiempo. Estas ideas las cruzo con las sugeridas por François Hartog y las planteadas por Elías José Palti. Dado que busco operativizar sus planteamientos, muchas de las referencias
} 
A fin de lograr este propósito he optado por ordenar el texto que sigue en tres partes. La primera parte se concentra en describir -desde literatura especializada- los nexos que hubo entre la Revolución francesa arriba mencionada y el reino español. La segunda parte busca observar comparativamente las declaratorias de independencia de Haití y la de Estados Unidos, por considerarlas pertenecientes al mundo no español que, de una u otra forma, afectaron el clima de opinión con el que se articuló la ilusión de una época ${ }^{18}$. En la tercera parte, me concentraré en observar las declaratorias de independencia de Caracas (1811), Cartagena (1811), Antioquia (1813), Cundinamarca (1813), Tunja (1813), Valledupar (1813), Popayán (1814) y Panamá (1821). Cabe anotar que la selección de los casos obedece directamente al acceso documental, y aunque no son muchas las declaratorias incluidas en este ejercicio, si son una muestra suficiente para acercarse a comprender las transformaciones conceptuales de la cultura política moderna.

\section{Revolución francesa en el reino español.}

Mucho se ha escrito acerca de las conexiones e influencias que existieron entre el espíritu ilustrado francés y la revolución de aquel reino en la arena político-intelectual del reino de España ${ }^{19}$. No en vano, como se ha podido demostrar, la Francia ilustrada fue un referente cultural y político para España. Era tal el miedo que generaban las ideas ilustradas afrancesadas, que Carlos III buscó con pretextos disímiles evitar la penetración de ellas en su reino; por eso expulsó a los jesuitas, cerró universidades y buscó afianzar el tomismo, esto último no exactamente porque buscase la aprobación de Roma, sino más bien porque eran medidas que permitirían proteger a España de los aires modernistas que se vivían en el reino vecino $^{20}$.

El régimen de Carlos III se ha calificado como autoritario, no solo por estas medidas, sino por el estilo de gobierno en sí. Donde el conocimiento científico fue proscrito, lo mismo que la opinión pública y por supuesto se hizo censura a la prensa de entonces. El reino de Carlos III se caracterizaba por los principios morales asociados con lo religioso católico. En este reino, las tertulias se convirtieron en espacios de escape en las que las utopías de libertad se expresaban tangencialmente bajo el estilo cadalsiano ${ }^{21}$. Fue en este contexto que en el reino español se cultivó una suerte de cultura política de resistencia contra el absolutismo, en la que paulatinamente ganaba fuerza la idea de ser buen ciudadano antes que buen vasallo. Desde el ambiente intelectual español, se hizo oposición política permanentemente, de todos los tintes y de todos los tonos, con el uso de sátira, humor, poemas, noveletas y por medio

que aluden a estos autores son más una elaboración personal que una cita textual de sus planteamientos. Para detalles de las sugerencias teórico-metodológicas propuestas por estos autores ver: Koselleck, Futuro pasado... Hartog, Regímenes de historicidad... Thopmson, Costumbres en común...,13-28, 116-293. Keith Michael Baker, Inventing the French Revolution. Essays on French Political Culture in the Eighteenth Century (New York: Cambridge University Press, 1990), 4-5.

${ }^{18}$ Sobre los efectos tangenciales que de la independencia haitiana con las transformaciones políticas del imperio español ver: Rebecca Scott y Jean Hébrard, Papeles de libertad. Una odisea transatlántica en la era de la emancipación (Bogotá: Universidad de los Andes - ICANH, 2015).

19 Jean-René Aymes, España y la Revolución francesa (Barcelona: Crítica, 1989). Lluís Roura, “Guerra y ocupación francesa: ¿freno o estímulo para la revolución española?”, en La trascendencia del liberalismo doceañista en España y en América, Manuel Chust e Ivanna Frasquet (Valencia: Biblioteca ValencianaColección Historia, 2004), 13-30.

${ }^{20}$ Sánchez Blanco, Francisco. "Luces y oscurantismo", en El absolutismo y las luces en el reinado de Carlos III, Francisco Sánchez Blanco (Madrid: Marcial Pons, 2002), 121-249.

${ }^{21}$ Sánchez Blanco, "Luces y oscurantismo”, 125-127,130-132. 
del teatro ${ }^{22}$. Al considerar este ambiente, se puede sostener que la Ilustración francesa, la revolución -de ese mismo reino-, y las lógicas y dinámicas de la política española de finales del siglo XVIII e inicios del XIX, nos facilitan la comprensión de los orígenes del liberalismo occidental. En el seno de estos acontecimientos fue donde se modeló la idea del Estado moderno, que persiste hasta nuestros días. Es preciso señalar que dicho Estado moderno no ha sido estático, se ha armado con los debates políticos en el seno de diversas sociedades políticas, económicas e intelectuales -, y los correspondientes estratos de experiencia y horizontes de expectativa que han asumido, discutido y planteado.

Según Manuel Chust, en esta lógica contextual se engendró el espíritu revolucionario del momento doceañista, el mismo que abrió la puerta a tendencias pro democráticas con las que se luchó en los territorios de ultramar ${ }^{23}$. No obstante, es preciso enfatizar que dichas tendencias prodemocráticas, en realidad se tejieron sobre la trama de un liberalismo posilustrado y posrevolución, en el que se optó por ordenar a los Estados nuevos como repúblicas $^{24}$ fundamentalmente demoliberales. Estos nuevos Estados republicanos auparon la instauración de gobiernos democráticos -limitados- y facilitaron la identificación y simultánea formación de la ideología conservadora, que en el contexto del periodo estudiado se conoce como Antiguo Régimen, una metaestrategia que algunas veces fue reaccionaria dado que su objetivo era mantener vigente el statu quo previo a los actos revolucionarios.

En el caso español, la crisis política, económica e institucional que facilitó la transformación del Estado, se empezó a gestar en los tiempos del gobierno de Carlos III ${ }^{25}$ y culminó durante la monarquía de Fernando VII. Estas dos monarquías significaron, políticamente hablando, la fase de transformaciones y crisis económicas que aceleraron los conflictos entre el Estado monarquista y la sociedad. Así las revueltas se fueron convirtiendo en el pan diario, especialmente en el régimen provincial ultramarino, donde la agencia de los levantamientos aumentó a finales del siglo XVIII, por la inconformidad que las reformas borbónicas causaron entre los pobladores del reino ultramarino ${ }^{26}$. Dichas reformas no solo impulsaron las protestas y los levantamientos referidos, sino que afectaron la estructuración de los cuadros burocráticos que le dieron forma a la administración del reino, ratificándolo como un Estado unificado de tendencias modernas ${ }^{27}$.

Como parte de la transformación de la semántica política del periodo 1780-1821 acá estudiado, la Revolución francesa y sobre todo el pensamiento ilustrado afectaron el valor y sentido de la idea de patriotismo y patriota. El patriotismo dejó de entenderse en la forma antigua -ligado casi exclusivamente con el lugar de nacimiento o naturalidad de origen de cada sujeto político- y se empezó a asociar con la idea de tomar partido o posición, idea que aludía directamente a los procesos revolucionarios de 1789 y 1793 . Así se instaló el primer patriotismo en el que se encapsularon otros conceptos de la politicidad moderna posterior

\footnotetext{
${ }^{22}$ Sánchez Blanco, “Luces y oscurantismo”, 135-136.

${ }^{23}$ Chust y Frasquet, La trascendencia del liberalismo doceañista ...,10-11.

${ }^{24}$ Régis Debray, La República explicada a mi hija (México: Fondo de Cultura Económica, 2002).

25 John Lynch, "El Estado borbónico", en La España del siglo XVIII, Francisco Sánchez Blanco (Barcelona: Crítica, 1991), 261-294. Sánchez Blanco, Francisco. "Luces y oscurantismo”.

${ }^{26}$ John Leddy Phelan, El pueblo y el rey. La revolución comunera en Colombia, 1781 (Bogotá: Carlos Valencia Editores, 1980).

${ }^{27}$ John Leddy Phelan, "El auge y la caída de los criollos en la audiencia de Nueva Granada, 1700-1781”, Boletín de Historia y Antigüedades, Órgano de la Academia colombiana de Historia, Volumen LIX, N 697-698 (1972): 597-618.
} 
como son: republicanismo, democratismo, liberalismo, socialismo, imperialismo, comunismo, nacionalismo e incluso fascismo ${ }^{28}$.

Semántica política que, en el siglo XX, atizó los aires belicosos de algunas mentes latinoamericanas que se oponía a las formas de la política mundial propias de la guerra fría, y que adoptaron como sinónimos los vocablos patria, patriotismo, patriota y revolucionario. Lo que el estudio del contenido acontecimental y semántico de estos vocablos denota es que las transformaciones políticas de finales del siglo XVIII e inicios del XIX, contribuyeron a forjar la cultura política revolucionaria latinoamericana de la segunda mitad del siglo XX; en razón a que, entre 1780 y 1821 , en los territorios provinciales españoles se concibió como patriota al sujeto político que competía con el soberano ${ }^{29}$.

El patriotismo derivado del periodo 1780-1821, expresó que "solo puede ser patriota quien actúa autónomamente bajo un gobierno libre" 30 . Semejante idea puso en tela de juicio la de la soberanía, así como la de la legitimidad política, y le dio impulso y sentido a la de libertad y liberal moderno. Estas últimas engendrarían posteriormente el liberalismo político con el que se pensó tanto el derecho constitucional como la idea de libertad. La idea de libertad engendró no solo la ideología liberal, sino que instó el surgimiento de otras ideologías $^{31}$ como el socialismo, el conservadurismo e incluso el comunismo; esto es fundamental para comprender las matrices del pensamiento político moderno y sus derivaciones contemporáneas. En el seno de este cambio de la semántica política reside la transformación del pensamiento jurídico, pues la soberanía pasó de ser entendida desde el derecho natural medieval para convertirse en parte del derecho liberal absoluto propio del siglo XIX.

De esta manera se observa que los hechos del 14 de julio de 1789, no solo tuvieron consecuencias en Francia, sino también en España. En el primer caso, lanzaron a la arena pública a hombres como M. Robespierre o Jean Paul Marat; mientras que en el segundo caso, fueron los rostros de: José de Iturrigaray, Miguel Hidalgo y Costilla en el Virreinato de la Nueva España, Bernardo de Monteagudo, Mariano Moreno en el Virreinato del Río de la Plata, Francisco de Miranda en la Capitanía General de Venezuela, Joaquín de Caycedo y Cuero en la Audiencia de Cali, Francisco José de Caldas, Camilo Torres en la de Santafé de Bogotá, entre una extensa lista de otros nombres. Sin embargo, más allá de los individuos lo que estaba en juego era la arremetida de una nueva idea de ordenamiento estatal, que en el reino español se tradujo en dos posturas: una que buscó protegerse cerrando fronteras a todo lo que tuviera aires afrancesados; ${ }^{32}$ y otra que por el contrario acogió lo afrancesado como un estilo político vanguardista, en el que se conjugaron estéticas y formas de hacer política.

\footnotetext{
${ }^{28}$ Reinhart Koselleck, Historias de conceptos. Estudios sobre semántica y pragmática del lenguaje político y social (Madrid: Editorial Trotta, 2012), 143.

${ }^{29}$ Koselleck, Historias de conceptos..., 145.

${ }^{30}$ Koselleck, Historias de conceptos..., 146.

${ }^{31}$ La literatura es abundante sobre el problema de las ideologías. Para efectos de la elaboración de este escrito se revisaron las siguientes entradas: Roucek y Müller, "Historia del concepto de ideología", 665-694. Ricoeur Paul, Ideología y utopía (Barcelona: Gedisa, 2001). Slavoj Zizek, Ideología: un mapa de la cuestión (Buenos Aires: Fondo de Cultura Económica, 2003). Robert Nozick, Anarquía, Estado y utopía (México: Fondo de Cultura Económica), 198. Eduardo Domínguez Gómez, comp. Historia de las ideologías políticas. Proyecto Agora. (Fondo Editorial Universidad Eafit, 2008).Marx Karl, "Tesis sobre Feuerbach", en Obras escogidas. Tomo I, K. Marx y F. Engels (Moscú: Editorial Progreso, 1973), 7-15, 21, 23.

Roura, "Guerra y ocupación francesa: ¿freno o estímulo para la revolución española?”, 27

32 Jean-René Aymes, "España y la Revolución francesa: ensayo de bibliografía crítica”, en España y la Revolución francesa, Jean-René Aymes (Barcelona: Crítica, 1989), 31-35.
} 
En este contexto considero que las declaratorias de independencia, efectuadas en los territorios ultramarinos del reino español, al igual que la toma de La Bastille, simbolizaron la crisis de un estilo de administración pública que no era otra cosa que un cuestionamiento a la estructura del Estado hasta entonces conocido. Al respecto Lluís Roura afirma: "La referencia a la revolución francesa impregna, en efecto, cualquier referencia revolucionaria en el ámbito peninsular, tanto en 1793 como en 1808"33.

Es así como a pesar de las medidas tomadas por Carlos III, las ideas revolucionarias francesas penetraron el reino español -vía el pensamiento ilustrado -, eso sí con límites ${ }^{34}$. La religión y el patriotismo fueron los muros de defensa de España ante sus revolucionarios vecinos franceses; ambos -religión y patriotismo- le dieron surgimiento a un "nuevo pensamiento y lenguaje políticos" 35 , en el que la censura, la apologética y las cruzadas patriotas católicas, construyeron la idea de revolución asociada con liberalismo y con caos, anarquía e irreligiosidad. De este modo las tendencias conservadoras empezaron carrera, con base a los pilares: "Dios, patria y rey"36. Al respecto, L. Roura advierte: "la Ilustración no era 'revolución', pero a estas alturas las formulaciones ilustradas todavía pudieron parecer a algunos como una fórmula para reconocer ciertos principios proclamados por la revolución, y esquivar al mismo tiempo las consecuencias por las que había pasado la sociedad francesa" ${ }^{\prime 3}$. Así las cosas, el liberalismo español que se deriva de este periodo, no pensó al individuo exclusivamente, sino que antepuso la nación de carácter católico, monárquico y confesional $^{38}$ como el hilo de Ariadna de la nueva cultura política moderna.

En el caso español, la dinámica de transformación política, tuvo procesos similares a los derivados de la Ilustración en el reino de Francia. De ello dan cuenta acciones como las de José Moñino y Redondo, Conde de Floridablanca, quien forjó su politicidad en la consistencia y la dedicación al trabajo, idea que puede asociarse tangencialmente en el clima de opinión de la época, el cual empezaba a romper parcialmente con la cultura política de los privilegios y coqueteaba con una suerte de cultura política semiliberal. Como puede observarse, el espíritu ilustrado no fue extraño en la corte española y aunque para algunos se leía como una moda afrancesada, influyó en el diseño de la fiscalidad del reino español. Este último aspecto, a mi modo de ver, fue el punto de inflexión para que el temido árbol de la libertad $^{39}$ germinase.

\section{Haití y las Trece Colonias: dos utopías de futuro-pasado.}

A finales del siglo XVIII las lógicas y dinámicas del intercambio económico y político, empezaron a transformarse, constituyendo así el sistema mundial moderno cuya columna vertebral se vincula con el liberalismo; ideología que permitió diseñar Estados políticamente republicanos y económicamente capitalistas. En este contexto, el reino de España quedó tangencialmente rezagado, tanto en su matriz productiva -si se le compara con las lógicas del intercambio inglés, holandés y francés-, como en la concepción de Estado. Esta última en el mundo no español caminaba hacia los regímenes demoliberales, como lo hizo en

\footnotetext{
${ }^{33}$ Roura, “Guerra y ocupación francesa: ¿freno o estímulo para la revolución española?”, 14.

${ }^{34}$ Roura, “Guerra y ocupación francesa: ¿freno o estímulo para la revolución española?”, 19.

${ }^{35}$ Roura, “Guerra y ocupación francesa: ¿freno o estímulo para la revolución española?”, 20.

${ }^{36}$ Roura, “Guerra y ocupación francesa: ¿freno o estímulo para la revolución española?”, 21.

${ }^{37}$ Roura, “Guerra y ocupación francesa: ¿freno o estímulo para la revolución española?”, 20.

${ }^{38}$ Aymes, "España y la Revolución francesa: ensayo de bibliografía crítica”, 31-35.

39 Antonio Elorza, "El temido árbol de la libertad", en España y la Revolución francesa, Jean-René Aymes (Barcelona: Crítica, 1989), 69-117.
} 
Francia y Estados Unidos. Esta concepción estatal liberal que ató política con capitalismo, paulatinamente, fue liderada por Inglaterra desde 1780 y con una larga duración hasta la actualidad. $^{40}$

Por su parte, en el reino español, el pensamiento ilustrado así como el reformista, cuya meta era adecuarse a los tiempos de cambio mundial, desde la agencia de hombres como los condes de Floridablanca, Campomanes y el de Aranda -cada uno en su estilo -, buscó la implementación de reformas -económicas y de administración pública-que favoreciesen el crecimiento económico en los planos industrial y agrícola; sin embargo, la adecuación en cuanto a la innovación industrial en España se quedó en el papel. Por ejemplo, las reformas propuestas por Floridablanca nunca llegaron a materializarse y el reino se sumió en una profunda crisis política, impidiendo que el cambio de la matriz productiva española siguiera el mismo ritmo que en Inglaterra, Francia o inclusive en el recién formado estado independiente: Estados Unidos.

Lo que es paradójico en este contexto, es que Francia que libró sus batallas republicanas internas logró crecer en la lógica del capitalismo, a pesar de haber concentrado muchos de sus esfuerzos en las guerras napoleónicas, y del retraso que hasta el siglo XVIII había mostrado en la arena económica mundial. Inglaterra, por su parte, logró recuperarse económicamente de la separación que sus colonias americanas efectuaron en 1776. Pero este es el resultado de dos reinos: Inglaterra y Francia, transformados por múltiples acontecimientos. Las declaratorias de independencia de las Trece Colonias americanas y la de la isla de Saint Domingue fueron parte de esa gran transformación ${ }^{41}$ política y económica que contribuyeron a tejer las lógicas del mundo moderno al que me he referido hasta acá.

¿Cómo las declaratorias de independencia de las Trece Colonias británicas y la de Saint Domingue afectaron el ordenamiento del mundo occidental?, ¿por qué me remito a estos dos acontecimientos si el foco de mi análisis es observar las declaratorias de independencia de algunas poblaciones provinciales ultramarinas del reino español? En primera instancia, creo que considerar estos dos acontecimientos es una manera de acercarse a comprender eso que he denominado la transformación del clima de opinión de la época estudiada. De otra manera, considero importante pensar bajo la lógica de las historias conectadas, para comprender un poco más la complejidad política mediante la cual se ha tejido el mundo moderno. En la lógica de las historias conectadas, la historia conceptual adquiere relevancia, ${ }^{42}$ pues el sentido semántico que cada sociedad le imprime a su politicidad, como es el caso acá analizado, se conecta con el clima de opinión hegemónico en cada régimen de historicidad. ${ }^{43}$

Considerando esta premisa, observar la influencia del pensamiento ilustrado y el de la Revolución francesa en las declaratorias de independencia de Haití (1804) y Estados Unidos (1776) es acercarse a comprender las lógicas del futuro-pasado que se empezaban a

\footnotetext{
${ }^{40}$ Para detalles sobre el cambio del modelo económico vivido en el periodo estudiado ver: Eric Hobsbawm, La era del capital 1848-1875 (Barcelona: Editorial Crítica, 1998), 41-59. Eric Hobsbawm, La era de las revolución 1789-1848 (Barcelona: Editorial Crítica, 2001), 34-60. Eric Hobsbawm, La era del imperio 1848-1875 (Barcelona: Editorial Crítica, 1998), 42-64. Immanuel Wallerstein, El moderno sistema mundial. I. La agricultura capitalista y los orígenes de la economía-mundo europea en el siglo XVI. $8^{\text {a }}$ edición en español (México, D.F.: Siglo Veintiuno Editores, 1998), 93-183. Karl Polanyi, La gran transformación. Crítica del liberalismo económico (Madrid: Ediciones La Piqueta, 1989), 11-50.

${ }^{41}$ Desde luego, la expresión es prestada de la obra de Karl Polanyi, vinculada con la emergencia y el colapso de las sociedades de mercado, ver: Karl Polanyi, La gran transformación: los orígenes políticos y económicos de nuestro tiempo. Segunda edición (México: Fondo de Cultura Económica, 1992).

${ }^{42}$ Koselleck, The practice of Conceptual History. Timing..., 21-30.

${ }^{43}$ Hartog, Regímenes de historicidad..., 16, 20-21, 30, 130-180.
} 
esbozar en el clima de opinión de los reinos de Inglaterra, Francia, y tangencialmente en el de España. Así las cosas, libertad, liberal, independencia, y posteriormente liberalismo se convirtieron en sinónimos de la semántica política moderna. Estas palabras representaron la utopía del futuro-pasado bajo el cual se trazaron los horizontes de expectativa que sirvieron para la erección y posterior consolidación de los Estados decimonónicos.

En este punto es preciso anotar que quienes declararon las independencias, en los espacios provinciales ultramarinos - tanto españoles, como franceses y británicos- no fueron en sí mismos independentistas ni liberales, así como Maquiavelo no fue maquiavélico ni Marx marxista. Es por esto que remitirse al problema de las utopías en el plano de la historia conceptual, y específicamente a las utopías que se encapsularon en las declaratorias de independencia, es ciertamente una cuestión multivalente. ${ }^{44}$

¿Por qué asociar las declaratorias de independencias con la idea de las utopías? El primero en estudiar el tema de las utopías fue: Louis-Sébastien Mercier, en 1770, cuando escribió un texto acerca de un sueño que él tuvo sobre cómo sería la sociedad del año 2240. Su novela futurista se escribió justo en la coyuntura en la que el mundo occidental estaba en crisis política y económica. ${ }^{45}$ De ello dan cuenta, no solo la división polaca de entonces, sino $-\mathrm{y}$, sobre todo- los procesos de revolución política acaecidos en el hemisferio occidental, específicamente en las provincias ultramarinas españolas, y en las colonias francesas y británicas.

Por todo lo anterior, considero que las declaratorias de independencia de la actual América Latina, fueron las utopías del futuro demoliberal que nos sigue retando en la historia del tiempo presente. ${ }^{46}$ Estas declaratorias representaron los horizontes de expectativa forjadas desde los estratos de experiencia de quienes las declaraban. En ellas trazaban los principios políticos, económicos, éticos e incluso hasta morales con los que imaginaban orientar el futuro de una nueva sociedad en la que la libertad era la lógica de la soberanía política. Esas declaraciones a modo de utopías, eran los lineamientos mediante los cuales los liberales del periodo 1780-1821 pensaban que podrían cristalizar el mundo moderno demoliberal y capitalista. Por un lado, transformarían el concepto de libertad, así como el de soberanía; y por otro lado, modificaría las prácticas de gobierno, ya que obligó a diseñar sistemas de partidos y electorales acordes con la nueva forma de percibir el mundo político.

Dichas declaratorias eran una serie de documentos con los que, al mismo tiempo, se pretendía tener un mundo nuevo y un manifiesto de protección ante la irrupción del Gran Tirano que emergía por aquella época: Napoleón Bonaparte. Ellas eran el nowhere y el now [w] here ${ }^{47}$ por construir; eran el a-hora de la política de finales del siglo XVIII e inicios del XIX; es decir, eran el lugar del ahora, el lugar sin el espacio y sin tiempo donde la libertad se entendía como sinónimo de independencia, autonomía, soberanía, heteronomía, felicidad, cambio y felicidad futura. Estas declaratorias se oponían al pasado que empezó a representarse como tiránico y bárbaro, tal como lo evidenció el texto haitiano.

Haití -que había sido parte de las provincias españolas de ultramar- fue cedida en su parte occidental a los franceses en 1697, esto implicó que el nombre de la isla cambiaría al

\footnotetext{
${ }^{44}$ Koselleck, The Practice of Conceptual History. Timing..., 84.

${ }^{45}$ Koselleck, The Practice of Conceptual History. Timing..., 84-85.

${ }^{46}$ Hugo Fazio Vengoa, La Historia del tiempo presente: historiografía, problemas y métodos (Bogotá: Universidad de los Andes, 2010).

${ }^{47}$ Koselleck, The Practice of Conceptual History. Timing..., 85-87.
} 
de Saint-Domingue. ${ }^{48}$ Desde la declaratoria de independencia (1804), es evidente cómo la élite política de la isla empezó a construir su horizonte utópico, en el que la relación estrecha entre la idea de libertad y la de patriotismo era prácticamente una sola, por eso se escribió:

Hoy primero de enero de mil ochocientos cuatro, el general jefe del Ejército indígena, acompañado de los generales, jefes del ejército, convocados para efecto de tomar las medidas que deben buscar la felicidad del país. Después de haber dado a conocer a los generales reunidos sus verdaderas intenciones, de asegurar para siempre a los indígenas de Haití un gobierno estable, objeto de su más sentida solicitud; lo que hizo por medio de un discurso cuyo propósito era dar a conocer a las potencias extranjeras la resolución de independizar al país y de gozar de una libertad consagrada por la sangre del pueblo de esta isla; y luego de haber recogido las opiniones, pidió que cada uno de los generales reunidos pronunciara el juramento de renunciar para siempre a Francia, de morir antes que vivir bajo su dominación, y de combatir hasta el último suspiro por la independencia.

Los generales, compenetrados con estos principios sagrados, después de haber adherido unánimemente al proyecto de independencia bien manifestado, juraron todos por la posteridad, por el universo entero, renunciar para siempre a Francia, y morir antes que vivir bajo su dominación. ${ }^{49}$

En esta declaratoria además puede apreciarse la influencia de la revolución de 1789, al asociar la libertad con la idea del patriotismo criollo. A su vez se ata con la utopía de la felicidad eterna, lo que es al mismo tiempo sinónimo de estabilidad política, traducida en la idea de una estabilidad gubernamental. En esta declaratoria, la libertad se entiende tácitamente y se afianza con la exigencia de renunciar políticamente al reino de Francia. Lo que llama la atención de esta declaratoria es el reconocimiento político de la población indígena a la que se incorpora como agente de gobierno al futuro isleño.

Posteriormente, el general en jefe de los ejércitos se dirigió al pueblo de Haití, otorgándoles la categoría de ciudadanos, palabra con la que implícitamente aludía a la transformación revolucionaria que se había vivido en Francia en el marco de su revolución. El uso del vocablo en cuestión encapsula el de libertad, y da cuenta de que el mundo político francés ya no se ordena bajo la monarquía absoluta de Louis XVI, denota que su soberanía ahora reside en el pueblo llano. La influencia de esta semántica política se extendió a los territorios ultramarinos y le dio sentido de independencia a la isla, que asumió la libertad como sinónimo de ciudadanía y al mismo tiempo de ruptura con la metrópoli y con su pasado monárquico. En la carta referida, el general J.J. Dessalines hizo un llamado de atención a la población al sostener que:

No es suficiente con haber expulsado de vuestro país a los bárbaros que lo han ensangrentado desde hace dos siglos; no es suficiente con haber frenado a las facciones siempre renacientes que os presentaban sucesivamente el fantasma de libertad que Francia exponía ante vuestros ojos. Se necesita un último acto de autoridad nacional: asegurar para siempre el imperio de la libertad en el país que nos vio nacer; arrebatar al gobierno inhumano, que mantiene desde hace tanto tiempo nuestros espíritus en la torpeza más humillante, toda esperanza de someternos. En fin, se debe vivir independiente o morir. Independencia o la muerte... que estas palabras sagradas nos unan, y que ellas sean el signo de los combates y de nuestra reunión. ${ }^{50}$

48 "Declaratoria de independencia de Haití, 1804", Archivos Nacionales del Reino Unido (Kew Richmond Surrey), volumen CO 137/111, http://www.nationalarchives.gov.uk/documentsonline/haiti.asp. Es preciso anotar que este documento me fue proporcionado por el historiador Armando Martínez Garnica, para efectos de la escritura de este texto. En adelante: "Declaratoria de independencia de Haitî".

49 "Declaratoria de independencia de Haití".

50 "Declaratoria de independencia de Haití". 
En este acápite se puede observar que la relación que el general establece entre libertad y utopía se sella en un pacto ficcional tejido con la muerte. De modo que la independencia se planteó más allá de la arena pública y de la política gubernamental, en ella se incorporó la promesa de salvación que el jacobinismo había planteado a los revolucionarios de 1789. En esta declaratoria de independencia se puede afirmar -junto a R. Koselleck- que como historiadores nos enfrentamos al dilema de la interpretación con "problemas constantes o perennes" que se han individualizado metodológicamente para hacerlos aprehensibles. De modo que estudiar el problema de la libertad, es un asunto persistente desde las postrimerías del siglo XVIII, es el reto utópico con el que se sigue tejiendo la semántica política moderna y contemporánea. Es por ello que la historia conceptual se piensa en la larga duración y como parte de la historia del tiempo presente, ${ }^{51}$ en razón a que el "pasado penetra en el presente. [...]. La frontera no es fija", ${ }^{2}$ pues nuestro presente es histórico, por lo cual "no existe un tiempo social de una sola y simple colada". 53

Más adelante, el general J.J. Dessalines incorporó los vocablos niños y niñas cuando sostuvo: "Ciudadanos indígenas, hombres, mujeres, niñas y niños: levantad vuestra mirada a todas partes de esta isla, buscad allí a vuestras esposas, vuestros maridos, vuestros hermanos, vuestras hermanas; más aún, buscad vuestros niños aún alimentados por el seno materno". De este modo aludía a la posibilidad de futuro, en tanto la infancia empezaba a modelarse como una nueva etapa de vida. ${ }^{54}$ En la misma carta, el general se dirigió al pueblo haitiano para recordarle su sacrificio personal. Se expuso como un héroe romántico que, de forma altruista, había entregado lo más preciado de sí, sus bienes, familia y su propia vida en pro de una utopía: la libertad. Es por ello que sostuvo:

\begin{abstract}
Y tú, pueblo tanto tiempo desafortunado, testigo del juramento que pronunciamos: recuerda que escon tu constancia y tu coraje con que conté cuando me lancé en la carrera por la libertad para combatir el despotismo y la tiranía contra los que luchabas desde hace catorce años. Recuerda que sacrifiqué todo para volar a tu defensa -padres, hijos, fortuna- y que ahora no tengo más riqueza que tu libertad; que mi nombre se ha convertido en el horror de todos los pueblos que quieren la esclavitud, y que los déspotas y los tiranos lo pronuncian solo para maldecir el día que me vio nacer; y si alguna vez rechazaras o recibieras murmurando las leyes que el genio que vela por tus destinos me ha dictado para tu felicidad, merecerías la suerte de los pueblos ingratos. Pero lejos de mí está esa horrible idea: serás el sostén de la libertad que deseabas y el apoyo del jefe que te dirige.

Pon entonces entre sus manos el juramento de vivir libre e independiente, y de preferir la muerte a todo aquello que tienda a subyugarte nuevamente. Jura, finalmente, perseguir por siempre a los traidores y a los enemigos de tu independencia. ${ }^{55}$
\end{abstract}

En estos apartados de la declaratoria de independencia haitiana, se puede apreciar cómo los seres humanos aprehenden sus realidades y las transforman en utopías en las que la conciencia y el dolor son fundamentales para asir y llenar de contenido la idea de libertad, pero sobre todo para construir la de patriotismo, un patriotismo ya no peninsular, sino isleño. Se trató de un patriotismo que se oponía a lo blanco desde lo indígena, creando así un nuevo

\footnotetext{
${ }^{51}$ Hugo Fazio Vengoa, La Historia del tiempo presente...

${ }^{52}$ Felipe Ruíz Martin, Prólogo a La historia y las ciencias sociales, de Fernand Braudel (Madrid: Alianza editorial, 1974), 14.

${ }^{53}$ Fernand Braudel, La historia y las ciencias sociales (Madrid: Alianza editorial, 1974), 29.

${ }^{54}$ Phillipe Ariès, El niño y la vida familiar en el Antiguo Régimen (Madrid: Taurus, 1987).

55 "Declaratoria de independencia de Haití".
} 
espacio de experiencia mediante el cual se representaba el futuro-pasado de una nueva nación por construir.

Ahora, en forma general, me acercaré al caso de las Trece Colonias británicas que le dieron sentido a Estados Unidos. Entre el 11 y el 28 de junio de 1776, Thomas Jefferson inició el bosquejo preliminar de lo que sería la declaración de independencia de las Trece Colonias británicas que le dieron origen al Estado nacional norteamericano que hoy conocemos. Esta declaratoria se conectó con la declaración de los derechos del hombre y el ciudadano que se efectuó posteriormente en Francia, en tanto en ambas se aludía al principio de igualdad como un factor trascendente para forjar la política del Estado nuevo. La relación de este principio con el de libertad se expresó en la declaración de independencia de las Trece Colonias de la siguiente manera: "We hold these truths to be self-evident, that all men are created equal, that they are endowed by their Creator with certain unalienable Rights, that among these are Life, Liberty and the pursuit of Happiness". ${ }^{56}$ Como puede apreciarse, la utopía de la libertad se tejió con las madejas de la igualdad y la felicidad.

El factor religioso no se dejó de lado, este se convirtió en parte esencial de la cultura política norteamericana. Sin embargo, se trató de una alusión al creador y no a la institucionalidad eclesial, por ello la religión se asumió más desde la lógica y los principios protestantes que negaban la necesidad de tener intermediarios en la relación espiritual que orientaría a la nación en formación. La defensa de los principios de igualdad y libertad que se hace en esta declaratoria, la ha convertido en un bien muy apreciado de la cultura política republicana, pues da cuenta de la transformación mental que la politicidad de finales del siglo XVIII estaba teniendo. Esta declaración es considerada junto a la declaración de los derechos del hombre y el ciudadano, uno de los manifiestos de libertad más apreciados de la cultura política moderna. La influencia de ambas ha sido tan grande que, aún en el presente, se les emplea para dar cuenta no solo de las utopías por realizar en varias partes de occidente, sino que se usan tácitamente para la lucha social que reclama la existencia, eficacia y eficiencia de los regímenes democráticos en general.

En la declaración de las Trece Colonias, la autoridad de los hombres se resaltó, pero a diferencia de la haitiana, los gobiernos se pensaron en positivo y no en oposición al pasado bárbaro y atroz que la colonia había tejido. En la declaración de independencia norteamericana se afirmó que los derechos de igualdad y libertad que tenían todos los hombres debían ser garantizados por los gobiernos, y que era perentorio cuidar colectivamente que esos derechos no se alterasen en ninguna forma o circunstancia. Por eso se expresó que en caso de que tales derechos se vieran comprometidos, el pueblo soberano sería el encargado de abolir los malos gobiernos. Esta condición puso sobre el papel el derecho consuetudinario europeo no continental, que desde el siglo XII había instaurado el Common Right y el Common Law. Así las cosas, en la declaración de independencia que refiero se lee:

(...) to secure these rights, Governments are instituted among Men, deriving their just powers from the consent of the governed, - That whenever any Form of Government becomes destructive of these ends, it is the Right of the People to alter or to abolish it, and to institute new Government, laying its

\footnotetext{
56 "The Declaration of Independence", America's Founding Documents, acceso noviembre de 2014, http://www.archives.gov/exhibits/charters/declaration_transcript.html

En adelante: "The Declaration of Independence".
} 
foundation on such principles and organizing its powers in such form, as to them shall seem most likely to effect their Safety and Happiness. ${ }^{57}$

En la misma declaratoria, la idea del maltrato, usurpación y coacción se incorpora para plantear la utopía liberal, de modo que se sostiene "The history of the present King of Great Britain is a history of repeated injuries and usurpations, all having in direct object the establishment of an absolute Tyranny over these States. To prove this, let Facts be submitted to a candid world". ${ }^{58}$ Este fragmento demuestra que el futuro político se deseaba y era en sí mismo deseo. En esta declaratoria, el repertorio político construye un lugar imaginado y soñado, donde las utopías del futuro se inspiran en la ruptura con un pasado traumático y aberrante del que se desea salir a construir un espacio de experiencia para no solo vivir con el deseo, sino declarar y construir otro tipo de realidad. Es por ello que se puede afirmar que las utopías que encierran tanto la declaración de independencia de Haití como la de las Trece Colonias británicas, son neologismos de perfección anclados en espacios imaginados, desde territorios reales y concretos. En ellas las temporalidades no existen, pues están cifradas en el porvenir que se piensa política y económicamente libre de la opresión británica y francesa respectivamente.

\section{Y... ¿cómo se tejió la libertad en el mundo neogranadino?}

El reino español en ultramar atravesó una etapa de crisis entre 1811 y 1821 , de la cual no logró reponerse. En ese lapso, la capitanía general de Venezuela asumió una nueva manera de expresar su politicidad. En su declaratoria de independencia -la primera proclamada en todo el régimen provincial español-, la idea de libertad se conectó con el diseño de un estado de ordenamiento republicano, en el que lo electoral se convirtió en la columna vertebral de las utopías por construir. ${ }^{59}$ Así las cosas, en la declaratoria de independencia efectuada en julio de 1811 en Venezuela, se ratificaba que el derecho natural otorgaba la gracia de "posesión de derechos", lo que los firmantes de la declaratoria reclamaban en nombre de la libertad de ejercer su soberanía. ${ }^{60}$ Lo interesante de esta declaratoria es que al aludir a la Corona española, se exhaló un halito de desilusión. Pues en España se consideraba a los venezolanos como revolucionarios, calificados implícitamente de apátridas y desertores de la Corona. En su declaratoria de independencia, los venezolanos se victimizaron al sostener que sus actos habían sido adelantados con el objetivo de defender el statu quo del reino y que:

A pesar de nuestras protestas, de nuestra moderación, de nuestra generosidad, y de la inviolabilidad de nuestros principios, contra la voluntad de nuestros hermanos de Europa, se nos declara en estado de rebelión, se nos bloquea, se nos hostiliza, se nos envían agentes a amotinarnos unos contra otros, y se procura desacreditarnos entre las naciones de Europa implorando sus auxilios para oprimirnos. ${ }^{61}$

\footnotetext{
57 “The Declaration of Independence".

58 "The Declaration of Independence".

59 Armando Martínez Garnica e Inés Quintero Montiel, La independencia absoluta de las provincias de Venezuela (Bucaramanga, 2008 [inédito]).

60 "Acta de la independencia de las Provincias de Venezuela", 5 de julio de 1811, en Historia de la revolución de Colombia, Tomo II, Capítulo VIII, nota 16, José Manuel Restrepo.

61 "Acta de la independencia de las Provincias de Venezuela".
} 
Visto de este modo, la declaratoria de independencia venezolana, representó para el reino español la distopía ${ }^{62}$ de su porvenir monárquico. Es decir, se trató del resquebrajamiento inicial de la utopía monarquista, según la cual, el reino era uno solo. Por eso la declaratoria de independencia venezolana significó la deformidad del sueño español de unidad política y jurídica. En esta declaratoria se conjugaron utopía y distopía como dos relatos independientes pero complementarios, en tanto ambos expresaban la latencia entre pasado y futuro; donde libertad, ruptura y continuidad se conjugaban en una sola semántica política, una semántica desdoblada que se estaba tejiendo para formar las lógicas y dinámicas de los Estados por venir.

En el mismo año, la provincia de Cartagena hizo su declaración de independencia. En ella la libertad se asoció implícitamente con la crisis de la monarquía y la invasión de los franceses en la península. En consideración con estos hechos, la declaratoria de independencia cartagenera sostenía que:

Con la irrupción de los franceses en España, la entrada de Fernando VII en el territorio francés, y la subsiguiente renuncia que aquel monarca y toda su familia hicieron del trono de sus mayores en favor del Emperador Napoleón, se rompieron los vínculos que unían al Rey con sus pueblos, quedaron éstos ${ }_{63}$ en el pleno goce de su soberanía, y autorizados para darse la forma de gobierno que más les acomodase.

Al igual que en la declaratoria venezolana, la cartagenera hacía referencia al término americanos como parte de la nueva semántica política, según la cual se establecía un distanciamiento con el pasado español y se tejía la senda del futuro. El vocablo encapsulaba las ideas de libertad e igualdad en una nueva dimensión, en la que los que firmaban estas declaratorias reclamaban sus derechos y privilegios como parte de su politicidad. En la declaratoria de independencia cartagenera, la utopía de libertad se consideraba frustrada por la actitud del gobierno monárquico, pues se consideraba que éste privilegiaba los asuntos de la política internacional en detrimento de la atención que la política local e interna del reino merecía. Por eso en la declaratoria se expresó que a pesar de que las autoridades -gobierno de regencia- en su momento: "Ofrecíanos libertad y fraternidad, y al mismo tiempo que proclamaban que nuestros destinos no estaban en manos de los Gobernadores y Virreyes, reforzaba la autoridad de éstos, dejándolos árbitros de la elección de nuestros representantes". 64

Dos años después las provincias de Antioquia, Cundinamarca, Tunja y Valledupar hicieron lo propio y se declararon independientes de la Corona española. En estas declaratorias, la libertad se asumió como la ruptura con el pasado y la posibilidad de elaborar

\footnotetext{
${ }^{62}$ Marcin Kazmierczac, "Entre la utopía y la distopía. La imagen del 'sur’ en los relatos de Jorge Luis Borges”, en El viaje en la literatura hispanoamericana: el espíritu colombino, VII Congreso Internacional de la AEELH, Sonia Mattalia, Pilar Celam y Pilar Alonso (Valladolid, 2006), 699-706.

63 "Acta de independencia de Cartagena de Indias", 11 de noviembre de 1811. El documento se ha publicado en Documentos para la historia de la provincia de Cartagena de Indias, hoy Estado Soberano de Bolívar en la Unión Colombiana, Manuel Ezequiel Corrales (Bogotá: Imprenta de Medardo Rivas, 1883), 351-356. Colombia. Itinerario y espíritu de la independencia según los documentos principales de la Revolución, Germán Arciniegas (Cali: Norma, 1969), 84-89. Documentos para la historia de Cartagena (1810-1812). Tomo 1, Roberto Arrazola (Cartagena: Concejo Municipal, 1963), 185-191. Documental concerniente a los antecedentes de la declaración de la independencia absoluta de la provincia de Cartagena de Indias, Gabriel Porras Troconis (Cartagena: Talleres de Artes Gráficas “Mogollón”, 1961), 77-83. En adelante: “Acta de independencia de Cartagena de Indias", 11 de noviembre de 1811.

64 "Acta de independencia de Cartagena de Indias", 11 de noviembre de 1811.
} 
un futuro distinto. Se trató de una politicidad en la que el futuro se conectaba con el pasado de manera que el presente se convertía en el puente indefinido entre ambos.

En la declaratoria de Antioquia la libertad se equiparó con la idea de justicia. Lo que llama la atención de esta declaratoria es su forma jurídica, pues ella da cuenta del formalismo aprehendido del pasado provincial y ajustado a la lógica de la policía moderna independentista y novedosa de la coyuntura de finales del siglo XVIII e inicios del XIX. Los antioqueños usaron los vocablos declara y decreta explícitamente, lo que denotaba que los firmantes no estaban explorando la aventura de separarse de la monarquía española; todo lo contrario, se trató de una declaración de principios en los que se reclamaba justicia al afirmar que en el pasado la injusticia había prevalecido. Este argumento sirvió para expresar una campaña política local en pro de la justicia, y así este vocablo se convirtió en el futuro utópico de libertad antioqueño que sentaba las bases para distanciarse del dominio español. En esta declaratoria como en la de Haití, los firmantes se dirigieron a los ciudadanos, lo que en la semántica política de entonces implicaba cuestionar el contenido político del vocablo soberanía. De modo que explícitamente se expresaba que la soberanía ya no residiría más en el rey, sino en el pueblo, y que los antioqueños se atribuirían el derecho medieval de autogobernarse por la ausencia de monarca. Este juego discursivo da cuenta de la gran transformación jurídica que los antioqueños empezaban a cristalizar para sí.

A diferencia de las anteriores declaratorias, la de Antioquia no es de principios políticos, sino de institucionalización de una nueva forma de hacer política, en la que prima la cultura jurídica como lo político de la política. ${ }^{65}$ Finalmente, otra distinción que posee la declaratoria de independencia de Antioquia, es que no se remite a la nación o al pueblo, sino que en ella se alude a la categoría de Estado. Esto demuestra que, en Antioquia, en 1813, la política se estaba tejiendo en una lógica institucionalizada, en la que se le dio peso a lo jurídico como parte de la semántica que estructuraría la formación y legitimación de una nueva unidad político-administrativa. Esta diferencia respecto a las otras constituciones, denota que Antioquia no estaba proyectando una utopía, sino que estaba materializando un proyecto de gobierno en el que el republicanismo, derivado de la idea de libertad que engendró el liberalismo posterior, era mucho más claro y tangible que en los casos que se han analizado hasta ahora.

Entre tanto en Cundinamarca, la declaratoria de independencia se planteó como parte de una preocupación utópica por la felicidad. En esta declaratoria se aludía a la nación, huérfana de gubernamentalidad, y se acusaba a los reyes de ausencia o más bien de desidia frente a las provincias de ultramar. En la de Cundinamarca, las alusiones al reino de Francia son una constante y se exponen más como un miedo tácito a la invasión napoleónica, la que implícitamente se asume como el apocalipsis del mundo conocido. En esta declaratoria, el pensamiento religioso denota cómo la cultura política cundinamarquesa se anclaba a la perfección con la tradición española de los Austrias. Lo que implicaba que el pasado era presente vivo y que el futuro buscaba deificar ese pasado anhelado. De manera que en lugar de expresar una utopía en todo el sentido de la palabra, lo que los cundinamarqueses expresaban era una nostalgia por ese pasado que sentían tan remoto. Así en la declaratoria de Cundinamarca se leía:

\footnotetext{
65 Para conocer detalles sobre la distinción de política y político a la que aludo implícitamente ver: Pierre Rosanvallon, Por una historia conceptual de lo político. Lección inaugural en el Collège de France (Buenos Aires: Fondo de Cultura Económica, 2003).
} 
En atención también al peligro que corre nuestra santa y adorable religión si permanecemos más tiempo en este estado, tanto por el riesgo que al finalizarse la conquista de España por los franceses nos quisieran estos obligar a reconocer la dependencia del Rey José Bonaparte, o la de trasladarnos a América al Rey Fernando, imbuido ya en sus máximas, y quizás rodeado de Ministros y tropas francesas, como por la falta bien sensible que en el día se nota de pastores eclesiásticos, no habiendo quedado en toda la Nueva Granada un solo Arzobispo ni Obispo que pueda ejercer las funciones de su ministerio, cuya falta nos iría insensiblemente reduciendo a la nulidad de ministros que prediquen el evangelio, administren los sacramentos y atiendan a la conservación y aumento de la religión; y que por lo mismo es de absoluta necesidad el que saliendo del estado de pupilaje, nos pongamos de acuerdo con las otras provincias que han hecho o hagan igual declaratoria en el de poder ocurrir al Padre Santo solicitando el remedio que cada día se hace más urgente. ${ }^{66}$

Por su parte, lo fundamental en la declaración de Tunja, publicada en diciembre de 1814, era el pueblo que se equiparaba a la categoría de nación. Las referencias geopolíticas en esta declaratoria, se planteaban como parte del entramado político que pensando desde el humanismo social buscaba implícitamente justicia. El encabezado se ratificó en el primer párrafo, allí los firmantes se dirigían en nombre del pueblo a los "habitantes de la tierra", 67 a quienes a modo de denuncia presentaban la declaratoria, cuyo sentido era resaltar los vejámenes de los que la población indígena había sido víctima desde el siglo XV. Al igual que en la declaratoria de independencia haitiana, en la tunjana también se incorporó el elemento indígena, población a la que se calificó de nacional. En las dos declaratorias, los indígenas fueron victimizados y se les presentó en una relación bipolar con los españoles, a quienes se sindicó de victimarios. En la declaratoria de independencia de Tunja, a diferencia de las declaratorias analizadas en este escrito, se incluye un nuevo vocablo: Colombia, territorio que se ubica geopolíticamente como "a una inmensa distancia de la Métropoli".

Como en las demás declaratorias, la ruptura con el pasado era evidente, se expresaba en las acusaciones del mal manejo gubernamental -el que implícitamente se asumía como un problema de administración de recursos-. Al respecto se afirmó que los indígenas habían sido explotados, mientras que los españoles, a quienes se catalogaba implícitamente de usurpadores, gozaban de mejores dádivas, tal como se evidencia en el siguiente fragmento:

Así se vio que éstos [españoles] fueron siempre los destinados a gobernar la América, obteniendo todos los empleos lucrativos, que se dotaban con crecidos sueldos, para empobrecer a los naturales y enriquecer a los aventureros que, abandonando su propio y fértil suelo, venían a mantenerse de ajenas producciones. La América desperdiciaba su sustancia en estos hombres que, lejos de servirla, se empleaban en su aniquilación para trasladarse después con los despojos al país de su origen. ${ }^{68}$

Asimismo, como parte de la denuncia de agravios, se especificaba que los españoles se habían interesado por mantener "la degradación y el embrutecimiento mismo de los

66 "Declaración de independencia de Cundinamarca", este documento ha sido publicado en Colombia. Itinerario y espíritu de la independencia según los documentos principales de la Revolución, Germán Arciniegas (Cali: Norma, 1969), 90-94. Los hombres del 20 de julio, Eduardo Ruiz Martínez (Bogotá: Universidad Central, 1996), 472-475. En adelante: "Declaración de independencia de Cundinamarca".

67 "Declaratoria de independencia de Tunja", este documento ha sido publicado en: Argos de la Nueva Granada (Tunja, 30 de diciembre de 1813), 34-35. Fray Andrés Mesanza, O.P., "La declaración de independencia de la República de Tunja", Boletín de Historia y Antigüedades 8, No. 95 (1913): 706-710. Historia de Tunja. Tomo II, Ramón C. Correa (Tunja: Imprenta Departamental, 1945), 161-164. En Adelante: "Declaratoria de independencia de Tunja”.

68 "Declaratoria de independencia de Tunja". 
americanos", a fin de poder ejercer el control político que facilitase el crecimiento económico e impidiera el desarrollo del conocimiento técnico. En cuanto a la libertad, se asumió como libertad económica, más que política y se conectó directamente con actividades económicas agrícolas y mineras. A propósito de estas actividades se sostuvo que eran el motor del mercado, el cual no estaba liberado, por lo que la nación colombiana se veía estrangulada y sometida ante sus tiranos. La idea de tiranía se incluyó para esbozar la utopía de un futuro libre. Esta declaratoria era un deseo de autonomía económica y administrativa, antes que un anhelo de libertad política exclusivamente, tanto que se afirmó:

Sería inútil hablar del sistema judicial, cuyos ministros hallaban la impunidad de sus delitos en la distancia y parcialidad de los tribunales europeos, si alguna vez llegaba a ellos la voz de la oprimida inocencia. En una palabra, todo se conjuraba contra los Pueblos de América: el comercio, la industria, el gobierno, los juicios, y hasta de la Religión Santa se abusaba para aumentar el peso de nuestras cadenas. Ningún ejemplo más notable de este trastorno político que la Provincia de Tunja, donde, en el largo espacio de tres siglos, no se fundó una escuela pública de primeras letras para la enseñanza de la juventud. Tampoco se interesaba el Gobierno en dar salida a sus ricas producciones, que se debían dar al consumo interno de sus habitantes, que, por la mayor parte, se hallaban en miseria espantosa, privándoseles de los bienes que hubieran podido adquirir con el sobrante de sus riquezas. Todos los cuidados de la Metrópoli se reducían a mandarnos un gobernante español que recogiese los impuestos con que se nos agobiaba, y que debían servir para mantener el lujo de su Nación. ${ }^{69}$

La utopía de libertad se acentúo con la metáfora: "Un grito de libertad se oyó en la Tierra del Fuego hasta la extremidad opuesta del continente". Con esta se subrayó la concepción binaria de la política asociada con la diada amigo-enemigo, víctima-victimario, que constituyó la latencia en esta declaratoria de independencia. En esta lógica dual la ausencia de libertad era como falta de autonomía, al tiempo que sinónimo de barbarismo o barbarie, de manera que en la declaratoria se leía:

Los bárbaros han renovado las escenas de la conquista. Ellos nos han suscitado enemigos dentro de nuestro propio cerro, seduciendo nuestros pueblos y obligándoles a tomar las armas contra propios hermanos para consumar de este modo sus atroces designios; han inmolado a su furor despótico los americanos más ilustrados, más virtuosos y amantes de su Patria; han hollado el derecho de gentes haciendo fuego, y asesinando cobarde y vilmente a los parlamentarios, cuyas personas son tenidas por santas, e inviolables, aún entre las naciones más bárbaras. ${ }^{70}$

Así las cosas, la independencia se asumió como una cuestión de libertad o muerte, era la salvación de la violencia atávica que los españoles ejercían sobre los americanos. Se enfatizaba el anhelo independentista de los tunjanos, como un deseo represado desde el 9 de diciembre de 1811. Lo que en cierto modo puede leerse como parte de la frustración por no haber podido materializar la utopía de la autonomía, que en este caso era sinónimo de libertad como ya he mencionado.

En la declaratoria de independencia de Valledupar, que es apócrifa, se destaca que la principal firmante es una mujer que se autodefine como "libre" y "de origen realista", pero ante todo "republicana". En esta lógica semántica se tejen el pasado y el futuro para declarar la libertad que se asume como sinónimo de "independencia". Lo que implícitamente está definiendo el sentido de la heteronomía que la libertad supone en cuanto a la autonomía de la soberanía para gobernarse como nación. El acta en referencia reza:

\footnotetext{
69 "Declaratoria de independencia de Tunja".
}

70 "Declaratoria de independencia de Tunja". 
Sea notorio a cuanto esta vieren, como yo, doña Concepción Loperena de Fernández de Castro, mujer libre de origen realista pero hoy republicana, a nombre del Cabildo de Justicia y Regimiento de esta ciudad ilustre, proclama libre e independiente a ésta ciudad de Valle de Upar del Gobierno Español, y la somete a los auspicios del Supremo Presidente S.S. Jorge Tadeo Lozano, y hace sabedores a todos los aquí presentes que la ilustre ciudad está por esta acta, ahora que son las diez de la mañana, libre y dispuesta a luchar por conseguir la libertad de todos los pueblos que guardan unión por el vínculo indescriptible del idioma y del pensamiento.

Pongo a disposición del General Simón Bolívar trescientos caballos de mis haciendas que llevaré en persona al ilustre General. En presencia de todos exijo juramento de fidelidad y quemo, por mis propias manos, los retratos y escudo de armas de S.M. y ordeno a nombre del cabildo de que hablo, poner los pechos valientes al sacrificio en aras de la libertad de los pueblos dirigidos por su excelencia Jorge Tadeo Lozano. En consecuencia firmo en la ciudad de Valle de Upar a los cuatro días del mes de febrero de $1813 .^{71}$

Como se puede observar, el lenguaje cambió sustancialmente, ello en razón a la condición de apócrifa de esta declaratoria, pues el paso del ojo del huracán revolucionario liberal, hizo que las posturas cambiasen rápidamente. Se puede observar cómo se configuró el clima de opinión en la matriz del liberalismo, hijo de la Ilustración y la Revolución francesa. Es significativo que sea una mujer la principal firmante del documento, pues el carácter apócrifo, tal vez pueda estar vinculado con este detalle, y no por la falta de certeza sobre su autenticidad, sino por el hecho de que bajo el régimen español a las mujeres "sólo en situaciones de hecho excepcionales se [les] reconocía"72 su plena capacidad jurídica. Las mujeres no eran sujetos emancipados ni heterónomos por completo, solo la viudez les otorgaba un lugar jurídico distinto y las hacía parte del todo político. De este modo, si una declaratoria de independencia iba encabezada por la firma de una mujer, puede inferirse que ello se emplearía como un recurso jurídico para denotar falsedad del documento. De esta manera se construirían los argumentos jurídicos que eximirían de responsabilidad criminal a los firmantes del documento, en caso de que la restauración monárquica triunfase.

En la declaratoria de independencia de Popayán, elaborada en 1814, la libertad se concibe en oposición a un pasado que se construye en el recuerdo como un momento de tiranía, se representa con un árbol que al mismo tiempo trae a la memoria la idea de justicia. Es por ello que se puede sostener que, en la declaratoria de independencia de Popayán, la libertad y la justicia son parte de un mismo paquete político que se opone al pasado tiránico y coercitivo. La ruptura con el pasado en esta declaratoria es tan fuerte que se afirma:

Se destruirán los retratos de los tiranos que desde la violenta ocupación de la América han usurpado los imprescriptibles derechos del hombre a pretexto de nuestra santa religión que de contrario abomina y condena la iniquidad y la depresión del género humano; se borrarán todos los signos del despotismo para no dejar a las generaciones futuras ni aun la triste memoria de unos monumentos tan degradantes, y se sustituirá en su lugar el del dulce nombre de JESÚS que visiblemente protege nuestra santa causa, extendiéndose el mismo a la cucarda provincial con el siguiente mote: EN ESTE SIGNO VENCERAS. Exceptuándose la moneda circular por corresponder su alteración al supremo congreso. ${ }^{73}$

\footnotetext{
71 “Acta apócrifa de independencia de Valledupar, 1813”. Es preciso anotar que este documento me fue proporcionado por el historiador Armando Martínez Garnica para efectos de la escritura de este texto. En adelante: "Declaratoria de independencia de Valledupar".

72 José María Ots Capdequí, El Estado español en las indias (México: Fondo de Cultura Económica, 1993 ), 95.

73 “Aurora de Popayán. Declaratoria de Independencia”. El Mensajero de Cartagena de Indias, n 21, Julio 1 de 1814.
} 
La libertad en esta declaratoria se asocia directamente con la idea de patria y patriotismo, de modo que se demuestra cómo Popayán había tomado su posición de partido en pro de la libertad de los modernos; es justamente por eso, que en la misma declaratoria se expresa visceralmente que se buscará eliminar toda traza de tiranía, pues al tomar partido patriota se está aludiendo al accionar político anclado en los ideales liberales de entonces. De este modo, Popayán sentó las bases para el nuevo diseño institucional del Estado, donde el derecho constitucional y la idea de libertad constituirían el hilo de Ariadna de la nueva cultura política y jurídica en gestación.

El ciclo de declaratorias de independencia que he optado por estudiar se cierra en 1821 con la de Panamá. ${ }^{74}$ Esta se publicó el 28 de noviembre de ese año, diez años después de las de Caracas y Cartagena. En la declaratoria de Panamá, la libertad se asoció con el diseño institucional del Estado, de modo que lo electoral fue el eje de toda la declaratoria, tal como pasó con la de Venezuela. Este aspecto denota cómo la transformación del pensamiento político estaba cada vez más asociado con un clima de opinión cada día más liberal, en el que la latencia por el lugar de la soberanía se solucionaba tácitamente incorporando la idea de la representatividad política, antes que el de la representación. En este sentido, la libertad fue parte del repertorio de la semántica política en el que la soberanía residiría en el pueblo, no en la nación. Como en el caso de Antioquia, esto da cuenta de que la utopía de libertad pasa de ser un sueño a ser una realidad más cercana y concreta para pensar el modelamiento del Estado moderno no monárquico. Así las cosas, en la declaratoria de independencia de Panamá se leía:

En Junta general de todas las corporaciones civiles, militares y eclesiásticas celebrada hoy 28 de noviembre de 1821, a invitación del excelentísimo Ayuntamiento, después de las más detenidas discusiones ante un numeroso pueblo y bajo el mayor orden y concordia, se convinieron y decretaron de común acuerdo los artículos siguientes:

$1^{\circ}$ Panamá, espontánea y conforme al voto general de los pueblos de su comprensión, se declara libre e independiente del gobierno español. ${ }^{75}$

En su artículo segundo, Panamá se afirmaba separada de España, pero se adhería a Colombia, lo que denota que la utopía unionista de la República de Colombia estaba pasando a ser una realidad que se fragmentaría a lo largo del siglo XIX; y cuya estocada final se produjo en 1898, con la emancipación del Estado Soberano de Panamá. Pero claro, ¡esa es otra historia! Lo interesante de esta declaratoria de independencia es el lugar y la valoración que, como en la de Antioquia, se le otorgó al derecho y a la emancipación. En el primer caso se aludió al derecho electoral con el que se sugería -implícitamente- un nuevo diseño institucional del Estado, y por supuesto al modelamiento del sistema de partidos que empezaba a pensarse en clave cada vez más moderna. ${ }^{76}$

\footnotetext{
74 “Declaración de independencia de Panamá", Gaceta de Colombia, № 14, 20 de enero de 1822. En adelante: "Declaratoria de independencia de Panamá".

75 "Declaratoria de independencia de Panamá".

${ }^{76}$ La discusión sobre lo que son los partidos políticos es tan amplia como la literatura que se vincula con el tema. Para ver lo más clásico de este asunto y que se acoge al tipo de partidos que se formaban en la primera mitad del siglo XIX ver, entre otros: Robert Mitchels, Los partidos políticos (Buenos Aires: Amorrortu, 2003). Manuel Alcántara y Flavia Friedenberg, coords. Partidos políticos de América Latina: países andinos (México D.F.: Fondo de Cultura Económica- Instituto Federal Electoral, 2003). Jhon Aldrich, Why Parties? The Origin and Transformation of Political Parties in America (Chicago: The University of Chicago Press, 1995).
} 
Lo que la lectura de estas declaratorias de independencia revela es la manera como se construyó el primer pilar del gran arco de los nuevos Estados modernos; y cómo en cada caso, la libertad fue asumida como una utopía para los que se declaraban independientes y una distopía para la Corona española que vio cómo su Estado se les escurrió entre los dedos. La libertad en las declaratorias que he comentado, puede equipararse al tesoro escondido de un pirata del que solo saben unos pocos. Como los tesoros de los piratas, la libertad incorporada en las declaratorias de independencia exigía la elaboración de mapas que pudiesen trazar las rutas para desenterrarla. Esos mapas serían las cartas constitucionales, mientras que las instrucciones para hallar dichos mapas estarían en las constituyentes, donde finalmente se toman todas las decisiones de la política moderna y contemporánea.

Finalmente, se puede sostener que estas declaratorias de independencia son virales en tanto se reprodujeron y multiplicaron sin medida, muchas veces en simultaneidad, y en todas se incorporó la idea de libertad. Esto denota que el clima de opinión del periodo 1780-1821, se alimentó del contractualismo y el iusnaturalismo propios del momento ilustrado europeo. La libertad, en todas estas declaratorias, fue el oxímoron de tiempo y espacio que buscaba romper con el pasado y construir un futuro con bases en ese mismo pasado que se quería olvidar. 


\section{Bibliografía.}

"Acta apócrifa de independencia de Valledupar, 1813".

"Acta de la independencia de las Provincias de Venezuela", 5 de julio de 1811. En Historia de la revolución de Colombia, Tomo II, Capítulo VIII, nota 16, José Manuel Restrepo.

"Acta de independencia de Cartagena de Indias", 11 de noviembre de 1811. En Documentos para la historia de la provincia de Cartagena de Indias, hoy Estado Soberano de Bolivar en la Unión Colombiana, Corrales Manuel Ezequiel, 351-356. Bogotá: Imprenta de Medardo Rivas, 1883.

“Acta de independencia de Cartagena de Indias", 11 de noviembre de 1811. En Documental concerniente a los antecedentes de la declaración de la independencia absoluta de la provincia de Cartagena de Indias, Gabriel Porras Troconis, 77-83. Cartagena: Talleres de Artes Gráficas "Mogollón”, 1961.

"Acta de independencia de Cartagena de Indias", 11 de noviembre de 1811. En Documentos para la historia de Cartagena (1810-1812). Tomo 1, Roberto Arrazola, 185-191. Cartagena: Concejo Municipal, 1963.

"Acta de independencia de Cartagena de Indias", 11 de noviembre de 1811. En Colombia. Itinerario y espíritu de la independencia según los documentos principales de la Revolución, Germán Arciniegas, 84-89. Cali: Norma, 1969.

America's Founding Documents. "The Declaration of Independence". Acceso noviembre de 2014. http://www.archives.gov/exhibits/charters/declaration_transcript.html

Archivos Nacionales del Reino Unido. "Declaratoria de independencia de Haití, 1804” (Kew $\begin{array}{llll}\text { Richmond } \quad \text { Surrey), } & \text { volumen } & \text { CO } & \text { 137/111. }\end{array}$ http://www.nationalarchives.gov.uk/documentsonline/haiti.asp.

"Declaración de independencia de Cundinamarca". En Colombia. Itinerario y espíritu de la independencia según los documentos principales de la Revolución, Germán Arciniegas, 90-94. Cali: Norma, 1969.

"Declaración de independencia de Cundinamarca". En Los hombres del 20 de julio, Eduardo Ruiz Martínez, 472-475. Bogotá: Universidad Central, 1996.

"Declaratoria de independencia de Tunja". En: Argos de la Nueva Granada. 34-35. Tunja, 30 de diciembre de 1813.

"Declaratoria de independencia de Tunja". En Historia de Tunja. Tomo II, Ramón C. Correa, 161-164. Tunja: Imprenta Departamental, 1945.

"Declaración de independencia de Panamá". Gaceta de Colombia, № 14, 20 de enero de 1822. 
"Declaration des droits de l'homme et du citoyen". Acceso noviembre de 2014. http://www.legifrance.gouv.fr/Droitfrancais/Constitution/Declaration-des-Droits-de1-Homme-et-du-Citoyen-de-1789

\section{Libros.}

Alcántara, Manuel y Flavia Friedenberg, coords. Partidos políticos de América Latina: países andinos. México D.F.: Fondo de Cultura Económica-Instituto Federal Electoral, 2003.

Aldrich, Jhon. Why Parties? The Origin and Transformation of Political Parties in America. Chicago: The University of Chicago Press, 1995.

Ariès, Phillipe. El niño y la vida familiar en el Antiguo Régimen. Madrid: Taurus, 1987.

Aymes, Jean-René. España y la Revolución francesa. Barcelona: Crítica, 1989.

Baker, Keith Michael. Inventing the French Revolution. Essays on French Political Culture in the Eighteenth Century. New York: Cambridge University Press, 1990.

Braudel, Fernand. La historia y las ciencias sociales. Madrid: Alianza editorial, 1974.

Calderón María Teresa y Clément Thibaud. La majestad de los pueblos en la Nueva Granada y Venezuela, 1780-1832. Bogotá: Taurus, 2010.

Clark, Gregory. Adiós a la sopa de pan, hola al sushi. Breve historia económica mundial. Valencia: Universitat de Valencia, 2014.

Debray, Régis. La República explicada a mi hija. México: Fondo de Cultura Económica, 2002.

Domínguez Gómez Eduardo, compilador, Historia de las ideologías políticas. Proyecto Agora. Fondo Editorial Universidad Eafit, 2008.

Fazio Vengoa, Hugo. La Historia del tiempo presente: historiografía, problemas y métodos. Bogotá: Universidad de los Andes, 2010.

Garrido, Margarita. Reclamos y representaciones-variaciones sobre la política en el Nuevo Reino de Granada, 1770 - 1815. Bogotá: Banco de la República, 1993.

Guardino, Peter. El tiempo de la libertad. La cultura política popular en Oaxaca, 1750-1850. Universidad Autónoma Metropolitana-Unidad Iztapala/Universidad Autónoma Benito Juárez de Oaxaca/Colegio de Michoacán/Colegio de San Luis/Congreso del Estado de Oaxaca/Durham and London, Duke University Press, 2005.

Hartog, François. Regímenes de historicidad. México D.F.: Universidad IberoamericanaDepartamento de Historia, 2007. 
Hobsbawm, Eric. La era del capital capital1848-1875. Barcelona: Editorial Crítica, 1998.

Hobsbawm, Eric. La era de la revolución 1789-1848. Barcelona: Editorial Crítica, 2001.

Hobsbawm, Eric. La era del imperio 1848-1875. Barcelona, Editorial Crítica, 1998.

Jaimes Peñaloza, Sonia Milena. Teatrocracia y legislación electoral colombiana (18861938). Un estudio de y sobre cultura política y democracia. Bogotá: Universidad del Rosario, 2012.

Koselleck, Reinhart. Futuro pasado. Para una semántica de los tiempos históricos. Barcelona: Paidós, 1993.

Koselleck, Reinhart. Historias de conceptos. Estudios sobre semántica y pragmática del lenguaje político y social. Madrid: Editorial Trotta, 2012.

Koselleck, Reinhart. The practice of Conceptual History. Timing History, Spacing Concepts. Estados Unidos de América: Stanford University Press, 2002.

Marx Karl. “Tesis sobre Feuerbach”. En Obras escogidas. Tomo I, K. Marx y F. Engels, 715, 21, 23. Moscú: Editorial Progreso, 1973.

Mitchels, Robert. Los partidos políticos. Buenos Aires: Amorrortu, 2003.

Nozick, Robert. Anarquía Estado y utopía. Fondo de Cultura Económica: México, 1988.

Ots Capdequí, José María. El Estado español en las indias. México: Fondo de Cultura Económica, 1993.

Palti, Elías José. El tiempo de la política. Lenguaje e historia en el siglo XIX. Buenos Aires: Siglo XXI, 2007.

Phelan, John Leddy. El pueblo y el rey. La revolución comunera en Colombia, 1781. Bogotá: Carlos Valencia Editores, 1980.

Polanyi, Karl. La gran transformación. Crítica del liberalismo económico. Madrid: Ediciones La Piqueta, 1989.

Polanyi, Karl. La gran transformación: los orígenes políticos y económicos de nuestro tiempo. Segunda edición. México: Fondo de Cultura Económica, 1992.

Ricoeur Paul. Ideología y utopía. Barcelona: Gedisa, 2001.

Rosanvallon, Pierre. Por una historia conceptual de lo político. Lección inaugural en el Collège de France. Buenos Aires: Fondo de Cultura Económica, 2003. 
Ruíz Martin, Felipe. Prólogo a La historia y las ciencias sociales, de Fernand Braudel. Madrid: Alianza editorial, 1974.

Sánchez Blanco, Francisco. "Luces y oscurantismo". En El absolutismo y las luces en el reinado de Carlos III, Francisco Sánchez Blanco, 121-249. Madrid: Marcial Pons, 2002.

Scott, Rebecca y Jean Hébrard. Papeles de libertad. Una odisea transatlántica en la era de la emancipación. Bogotá: Universidad de los Andes - ICANH, 2015.

Silva Prada, Natalia. "Pasquines contra visitadores reales: opinión pública en las ciudades hispanoamericanas de los siglos XVI, XVII y XVIII”. En Opinión pública y espacio urbano en la Edad Moderna, dir. por James S. Amelang y Antonio Castillo Gómez, ed. por Carmen Serrano, 373-398. Gijón: Ediciones Trea S.L., 2010.

Silva Prada, Natalia. "Los reinos de las indias" y el lenguaje de denuncia política en el mundo Atlántico (s. XVI-XVII). Charleston: Create Space, 2014.

Stern, Steve (compilador). Resistencia, rebelión y conciencia campesina en los Andes. Siglos XVIII- XX. Lima: Instituto de Estudios Peruanos- IEP, 1990.

Thopmson, E. P. Costumbres en común. Barcelona: Crítica, 1995.

Wallerstein, Immanuel. El moderno sistema mundial. I. La agricultura capitalista y los orígenes de la economía-mundo europeo en el siglo XVI. $8^{\text {a }}$ edición en español. México, D.F.: Siglo Veintiuno Editores, 1998

Wallerstein, Immanuel. El moderno sistema mundial. El triunfo del liberalismo centrista, 1789-1914. México: Siglo XXI Editora Iberoamericana S.A., 2014.

Zizek, Slavoj. Ideología: un mapa de la cuestión. Buenos Aires: Fondo de Cultura Económica, 2003.

\section{Artículos y capítulos de libro.}

"Aurora de Popayán. Declaratoria de Independencia". El Mensajero de Cartagena de Indias, $\mathrm{N}^{\mathrm{o}} 21$, julio 1 de 1814 .

Aymes, Jean-René. "España y la Revolución francesa: ensayo de bibliografía crítica”. En España y la Revolución francesa, Aymes Jean-René, 31-35. Barcelona: Crítica, 1989.

Calderón, María Teresa y Clément Thibaud. "La construcción del orden en el paso del antiguo régimen a la república. Redes sociales e imaginario político del Nuevo Reino de Granada al espacio Grancolombiano". Anuario Colombiano de Historia Social y de la Cultura, $\mathrm{N}^{\circ} 29$ (2002): 135-165. 
Elorza, Antonio. "El temido árbol de la libertad". En España y la Revolución francesa, Aymes Jean-René, 69-117. Barcelona: Crítica, 1989.

Feijoo, Germán y Zolia Ubillus. "Levantamientos populares coloniales: Hato de Lemos 1781”, Revista Región, № 5 (1996): 35-59.

Hunt, Lynn. “Modernity: Modern Times Different?” Historia Crítica, No 54 (2014): 107124.

Kazmierczac, Marcin. "Entre la utopía y la distopía. La imagen del 'sur' en los relatos de Jorge Luis Borges". En El viaje en la literatura hispanoamericana: el espíritu colombino, VII Congreso Internacional de la AEELH, Sonia Mattalia, Pilar Celam y Pilar Alonso, 699-706. Valladolid, 2006.

Lynch, John. "El Estado borbónico". En La España del siglo XVIII, Francisco Sánchez Blanco, 261. Barcelona: Crítica, 1991.

Martínez Garnica, Armando y Inés Quintero Montiel. La independencia absoluta de las provincias de Venezuela. Bucaramanga, 2008 [inédito].

Melo, Jorge Orlando. "Algunas consideraciones globales sobre 'modernidad' y "modernización". En Colombia. El despertar de la modernidad, compilado por Fernando Viviescas y Fabio Giraldo. Bogotá: Ediciones Foro Nacional por Colombia, 1991.

Mesanza, O.P., Fray Andrés. "La declaración de independencia de la República de Tunja". Boletín de Historia y Antigüedades 8, No. 95 (1913): 706-710.

Orjuela, Luis Javier Orjuela. "La tensión entre tradición y modernidad (1904-1995)”. En Historia de las ideas políticas en Colombia. De la independencia hasta nuestros días, Javier Ocampo López. Bogotá: Taurus, 2008.

Phelan, John Leddy. "El auge y la caída de los criollos en la audiencia de Nueva Granada, 1700-1781”. Boletín de Historia y Antigüedades. Órgano de la Academia colombiana de Historia, Volumen LIX, Nº 697-698 (1972): 597-618.

Roura, Lluís “Guerra y ocupación francesa: ¿freno o estímulo para la revolución española?”. En La trascendencia del liberalismo doceañista en España y en América, Manuel Chust e Ivanna Frasquet, 13-3. Valencia: Biblioteca Valenciana- Colección Historia, 2004.

Roucek, Joseph S. y Ángela Müller Montiel. "Historia del concepto de ideología”. Revista Mexicana de Sociología 25, № 2 (1963): 665-694.

Silva Prada, Natalia. "Cultura política tradicional y opinión crítica: los rumores y pasquines iberoamericanos de los siglos XVI al XVIII". En Tradición y modernidad en la historia de la cultura política (siglos XVI-XX), coordinado por Riccardo Forte y 
Natalia Silva Prada Natalia, 89-143. México D.F.: Universidad Autónoma Metropolitana -Unidad Iztapalapa, 2009. 